\title{
Locked Out but Holding Together in Ravenswood
}

The first in a two-part series that details the Steelworkers' victory at Ravenswood Aluminum - one of labor's biggest wins in the '90s.

Tom Juravich

University of Massachusetts - Amherst

Kate Bronfenbrenner

Cornell University

When Ravenswood Aluminum Company (RAC) locked out seventeen hundred workers on October 31, 1990, it hardly looked like a big opportunity for labor.

In what had become standard operating procedure for employers during the 1980s, management broke off bargaining with the United Steelworkers of America (USWA), and then brought hundreds of replacement workers into a heavily fortified plant surrounded by barbed wire and security cameras. Injunctions prevented union members from doing much more than symbolic picketing, and the wheels of justice, as they had done for more than a decade, creaked ever so slowly.

All the pieces were in place for another long, drawn-out defeat for labor.

Like so many other workers and unions over the past two decades, the locked-out workers at Ravenswood were facing something unfathomable, even in the context of their toughest bargaining in the past. Their plant, a flagship operation of Kaiser Aluminum when it first opened in the 1950s, had brought a middle-class lifestyle to their families in rural West Virginia.

In the late 1980s, it was sold in a leveraged buyout. The workers watched as new managementdriven to cut costs and increase profits-slashed jobs, cut staffing levels, and let working conditions deteriorate dangerously.

In all of this, they were up against a former plant manager, now CEO, who had returned to the plant with a personal grudge against the union.

And after many months the Steelworkers would discover a tangled web of overlapping owners and investors revealing that the company and their destiny were ultimately controlled by Marc Rich, a world renowned financier and metal trader, a fugitive from justice, and a notorious white-collar criminal hiding out in Switzerland. This would be no ordinary fight.

It would take almost two years, but, in the end, it was the Steelworkers who held out "one day longer" than the company, defying the pattern that emerged out of the 1980 s of broken unions and divided communities.

Without question, the victory was wrested from Ravenswood Aluminum by the tremendous determination and courage of the Steelworkers and their families. Even through the darkest times of the lockout, the members of Local 5668 held on and held together, far beyond what reason told them. In the twenty months of the lockout, only seventeen of their seventeen hundred members crossed the picket line. 
The lockout began at midnight on October 31, 1990, after the company refused the union negotiators' unconditional offer to work under terms of the old agreement until a settlement could be reached. The key issues involved health and safety, recouping wages and benefits lost in concessionary bargaining in the 1980s, and improving pensions for a workforce with an average age of fifty-three.

Just four months before the contract expired, Jimmy Rider, a thirty-eight-year-old crane operator who had worked a midnight shift, had been forced to work the next shift down on the pot room floor, where ore is heated to make molten aluminum. It had been three years since he had last worked there and he wasn't used to the heat.

Toward the end of his shift, Rider asked repeatedly to be allowed to leave because he felt ill, but the company nurse and his foreman refused. Rider lay down on the floor and told his fellow workers, "Boy, I'm too hot." He then died of a massive heart attack.

Three more workers died at Ravenswood during that long hot summer. But management steadfastly refused to bargain over health and safety issues that were key concerns of United Steelworkers negotiators. "We'll accept suggestions from you guys, but we don't want to negotiate on that," a company bargainer said.

A union negotiator responded that "there had been a death and workers were being hauled out packed in ice and that was all the information the parties needed to negotiate." But the company held firm and refused to bargain over the pot room.

RAC had not been idle in the meantime. Toby Johnson, a rank-and-file worker, explained: "We could see that they were getting ready for something 'cause they were clearing the brush along the hillsides, clearing all that out, and that was a big job. They worked on it a long time. And it's not a job you would do just to beautify the area."

The company also built a landing site for a helicopter. According to one local leader, "They come to our contracting committee, and said, 'We're going to build a helicopter pad.' 'What for?' we asked. 'So we can get people injured in and out of here.' Well, we knew better than that."

One salaried worker recalled, "We saw the orders coming through for bulletproof vests, Mace, and Mace holders. Food and entertainment were ordered." These were no ordinary strike preparations. As the contract expiration date came closer, RAC boarded up the windows in the main office building and erected a chain-link fence around the perimeter of the property, which was no small undertaking.

Heavy steel plates were installed in front of the massive electrical transformer station near the front of the property, surrounded by tractor-trailers filled with hay, designed to stop bullets from penetrating the transformers. The plant, especially the pot rooms, depended on the station for power. Even a relatively short interruption could cause the potlines to freeze up, costing millions in repair and restart costs.

With all those fortifications, the workers renamed the plant "Fort RAC." AI Toothman, RAC labor relations manager, later reported that the company had spent more than $\$ 2$ million on strike preparations.

At 9 p.m. on October 31, the company distributed its final offer: elimination of a metal price bonus, freezing of the cost-of living allowance, a 25-cent wage increase coupled with profit-sharing of 9 percent of pre-tax profits after $\$ 25$ million, and slight improvements in pensions. The final offer didn't even mention the union's concerns about health and safety. 
Everyone on the bargaining team could see that RAC was not interested in reaching an agreement that night, despite the union's offer to extend the old agreement rather than go out on strike. Joe Chapman, the union representative assigned to Ravenswood by the Steelworkers, wanted to do everything he could to avoid a strike. If he had to, he wanted to force the company into a lockout.

"I knew if 1 got them to lock us out, then under the laws of the state of West Virginia, we could draw unemployment.... 1 did not want to put a 1,700-person workforce out on the bricks, believe me," he said. "I've had eight or ten strikes in my time-there's not been easy ones."

When the clock moved past midnight, clearly bargaining was over. No last minute phone call. No final offers. The negotiations were finished, at least for a while.

As they sat there for a few minutes to make sure that nothing else was going to happen, the union committee was stunned. One of them called down to the union hall and got the bad news. The workers had been sent home. The union was locked out.

While the clock was running out on bargaining in Pittsburgh, Local 5668 members had gathered at the union hall back in Ravenswood, waiting for word from the negotiating committee.

"We had a meeting about ten o'clock, and the mood was that the eleven o'clock shift wasn't going in," recalled local vice president Bill Doyle, who, along with picket captain Bud Chenoweth and union attorney Stan Hostler, was in charge back at the local. Finally, Charlie McDowell, who chaired the grievance committee, called from Pittsburgh and told them that, whether the union settled or not, the midnight shift should report to work as planned.

The union was not on strike. But there was still no contract-not even an extension, "so it was a hell of a job out on the floor convincing those guys to go in," recalled Doyle. "Between Stan and myself and Bud Chenoweth and the guys that was here, we convinced them to go in."

Negotiations had gone down to the wire with Kaiser in the past, but at the last minute the contract had always been extended. In the end, they had always settled. Although RAC had acted very differently than Kaiser over the past months, as Bill Hendricks walked back into the plant that night, he and most of his fellow workers expected a settlement.

Tall and thin, Hendricks comes across Lincolnesque in both his gawkiness and sincerity. He had hired on in 1973, twenty-two years old, "fresh off the street," feeling lucky to have found a good job where he "wouldn't have to worry about nothing the rest of his life." At thirty-nine, he was one of the youngest workers in the plant, and one of the youngest union activists.

Hendricks had worked sixteen years in the pot room under Kaiser. Although most workers bid off the potlines at the first possible chance, Hendricks stayed. It was tough, hot work, but for Hendricks it was a "good place to fend for my family."

All that changed after RAC took over. The work got harder, the days seemed longer and, as a "safety man" for the union, he started worrying about the men. Then his good friend Jimmy Rider was killed on the job.

Still, despite all that had happened over the past few years, Hendricks went in with the rest of the midnight shift thinking there would be a settlement.

Hendricks had been on the job for less than an hour when the workers were ordered to pack their gear and get out. "Everybody leaves, everybody," the foreman told Hendricks. "They [told] us we had to leave with no contract.... 'Communications broke down. You'll have to leave.' Just an hour before, they told us to stay." 
As Bill walked back to his locker, he caught a glimpse through an open window of several buses sitting in the salaried workers' parking lot, engines running. He suspected that the buses were filled with scabs. The buses, marked Lakeshore Tours out of Cleveland, Ohio, had been on the plant grounds since late that afternoon.

The workers took their time leaving the plant. In Bill Hendricks's words, they "kind of hemhawed around." At one point workers blocked a doorway where some managers were congregated, "and they expected there was going to be a kind of, you know, fight right there in the hall."

Finally, "everybody made their way to the bathroom, to the shower room. Everybody showered. And I stayed. I was the last one to leave the pot rooms. After everybody showered I checked every stall. I didn't want none of my boys standing on a commode seat. You know, some of them guys wanted to stay pretty bad, so I looked. And I was the last vehicle to leave the parking lot, me and Red Shoemaker."

The company made sure the workers left nothing behind. They had been handed a notice a few days earlier, telling them to clean out their lockers before they left on October 31. That night the foremen stood over them, making sure their lockers were emptied.

As the last group of workers went into the parking lot, they were met by a wrecking truck waiting to tow away any workers' cars that had problems, or any cars left behind. It looked as though RAC was making a clean break with its current workforce, leaving nothing to chance. As the last union workers left the plant, the gate was locked behind them.

Not only were union workers locked out, the salaried and replacement workers were locked in. As instructed, salaried workers had reported at 7 p.m. that night carrying changes of clothes, toiletries, and a six months' supply of medication.

At first the mood was almost festive. One of the salaried workers reported, "it was like a big party," because, like the union workers, most believed a strike "wasn't going to happen." Although the preparations hadn't been nearly as intense, in past negotiations with Kaiser they had also been told to bring in their clothes and medication. But no strike had ever happened.

This time, however, by 1:20 a.m., as the last union worker left the plant, managers walked through the offices telling everybody that "the union has not signed the contract, so we're locking the gate." Some of the salaried workers from the data center walked into the parking lot and watched the union workers outside the fence.

It was especially hard on the seven salaried women whose husbands had just been locked out. As one told us, "You just couldn't believe that this was happening. It was like somebody in the family was dying. ... And when I left, I said, 'I'll probably see you [her husband] at one o'clock.' Well, it was three days later that I saw him.... I mean you're still inside the fence but you could see. And it was really sad to see the guys sitting out, standing out there...because they were as dumbfounded as everybody else. I mean, it really was just sad. Because there they were, locked out."

The replacement workers started filing into the plant just as the last group of union workers was being escorted to the gate. Some had waited in buses through the long afternoon and evening and were growing impatient. Several encounters occurred between union workers and their replacements, through doorways and down hallways. But neither words nor blows were exchanged, since neither the union workers nor those brought in to replace them fully comprehended what was happening. 
The salaried workers had already worked their full day shift before they came back in that evening. The company had set up a cafeteria and recreation room, but cots for sleeping were not set up until close to 4 a.m. Few got much sleep bunked on cots in unfamiliar surroundings.

Blurry-eyed at 6 a.m., they couldn't miss the locked-out Steelworkers picketing outside the gate. The company security guards were everywhere-along the fence and on every roof. The salaried women in particular had been warned by the company not to go anywhere alone for fear of union violence.

Yet, as they looked outside the fence, what they saw were their co-workers, their friends, and their neighbors.

After too little sleep, the salaried and replacement workers worked the first of many twelvehour shifts. While the replacement workers were assigned to work in the plant, the secretaries, payroll clerks, bookkeepers, and accountants replaced locked-out maintenance and janitorial staff.

The company rewarded them that first evening with a big dinner. Pool tables, basketball courts, and even televisions were provided, hooked up to two newly installed satellite dishes. In a display of generosity, they also provided a keg of beer, although everybody was limited to one glass.

After an exhausting drive from Pittsburgh on no sleep, the negotiating team arrived in Ravenswood at 5 a.m. They drove straight to the union hall, which is up on a ridge overlooking Route 2, midway between the town and the plant, just off Nu Chance drive, where Emmett Boyle, the company CEO, once lived with his family.

When the committee pulled into the parking lot that morning, it was jammed with cars lining both sides of Route 2 . The hall was packed. The mood was somber but focused.

Prior to negotiations, the local had elected picket captains and mapped out the plant, but had not done much more planning in case of a strike. Now plans were quickly pulled together, picket duties assigned, and picket signs made. But, instead of "On Strike," the signs read "Locked Out." Many went right down to the picket line not having slept at all that night.

Some dressed in camouflage, as their union brothers in the United Mine Workers of America (UMWA) had done in the long fight against the Pittston Coal Group a few years earlier. During the strike in southwestern Virginia in 1988, the miners, many of whom had served in Vietnam, adopted a uniform of camouflage. It not only reinforced the idea that they were fighting for their lives, but made identification of individuals by law enforcement difficult.

Many of the Steelworkers at Ravenswood had supported the UMWA strike, and even those who were not directly involved were connected in spirit, given their longstanding connection to the UMWA and the struggles in the coalfields.

The picket line was organized in four hour shifts, with the first workers reporting from midnight to 4 a.m. Not expecting a lockout, few had dressed for the picket line, and they shivered in the cold. Except for a handful of former UMWA members, most of those who picketed that night had never been on strike before. They really had no idea what to expect.

Bill Hendricks explained, "It was dead cold. We didn't expect it to get that cold. And when we went back around the curb to go down there, I was freaked. They'd fired those portable generators. They had portable lights that lit up through the bottoms down there like it was New York City. I'm telling you, I've been driving to that plant at nighttime for years. On midnight shift, you couldn't see anything. . .. It was daylight around that plant. Beat anything I ever seen. . . Matter of fact, you look in that light you could see fifty deer." 
Tensions increased when the company brought in a forty-member paramilitary-style security force the night of the lockout. Equipped with riot shields, clubs, and tear gas, dressed in dark paramilitary- style clothing, they looked ominous. They also carried video cameras and constantly filmed the activity on the picket line.

The guards stayed at their posts, not joining other RAC management employees except for meals, which they ate at separate tables. For those on the roof, buckets were passed up and down to bring them food.

Many of the workers saw the new arrivals, who soon came to be known as the "goon guards," as a personal affront. The workers felt they had done nothing wrong. In fact, it was the company that had locked them out. They were only exercising their legal right to picket, and to be met with this show of force was insulting.

Starting that first night, the goon guards seemed set on provoking a confrontation with the locked-out workers. They would challenge workers through the chain-link fence, calling them names.

The union was equally determined not to play into the company's hand. To avoid the kind of sensational confrontation that the goon guards were clearly trying to incite- and the court injunction limiting picketing that would soon follow-they pulled pickets from the front of the plant on the second day of the lockout and moved them out to Route 2.

As Joe Chapman recalled, the union had several reasons to move the pickets back: "When someone stands and throws an apple at you, pretty soon you're going to throw something back. So I didn't want that to happen.... I wanted to get the community, the public, everybody on our side. I wanted to put the company in the box of being the bad guy. And as quick as possible. And keep them there. And nail the lid shut on them."

The company issued a series of press releases declaring that impasse had been reached and that given the "unrealistic contract extension proposal of the Steelworkers... the corporation believes that the only way to guarantee a continued and secure operation is to utilize the current salaried workforce and to supplement these workers as necessary."

Ravenswood Aluminum also sent two mailings to the workers' homes, outlining its final offer and announcing that health benefits had been suspended as of November 2 .

On Saturday, three days into the lockout, union members gathered by shift in three meetings at the Ravenswood High School gym. They came to vote on the committee's decision to reject management's final offer and agree to work under the old agreement. By a vote of 1,100 to 13, the rank and file stood solidly behind their union committee.

Inside the plant 400 salaried workers and nearly 200 replacement workers labored round the clock to keep the plant running. For the first three days, they were locked inside the plant behind boarded-up windows and doors. Their only contact with the outside was phone calls closely monitored by the guards.

Over and over again, the company kept reminding them of the threat of violence from the hourly workers. "It was like a prison," one salaried worker remembered. "You couldn't see out. You didn't know what was going on outside. If it rained, you didn't know it. It's an awful feeling.... When they let us out, they let us out of prison."

Down the road from the plant, Local 5668 members walked the picket lines. Although the guards and the replacement workers continued to try to provoke the picketers, the situation remained 
fairly calm. The worst moments came when the scabs would drive out of the plant waving their paychecks in the faces of the locked-out workers.

The relative calm of the first three weeks of the lockout ended on November 25, when the goon guards marched en masse to one of the picket stations. Dressed in full riot gear, marching behind plexiglas shields, they demolished a picket shack, destroyed picket signs, and tore down an American flag that the Steelworkers had placed there.

The tension between the locked-out workers, "locked-in" salaried workers, and the scabs touched every aspect of daily life. For the union members, who had spent their entire adult lives working in the plant, the company and the scabs had stolen not only their jobs but their community.

"Well, you see a strange face or a new license plate in town, you think right away, 'There goes a damn scab,"' explained Local 5668 member Leonard Brown. "So you don't talk to people, you don't make new friends. People quit going to church be' cause of the conflict."

Sue Groves, wife of a locked-out union member, worked as the bookkeeper for Cope Supermarket for eighteen years. 'Within days of the lockout, she found herself cashing the checks of the replacement workers who had taken her husband's job and listening to their comments about the plant and the locked-out workers.

Unable to bring herself to pay the bills for a company that had crossed the picket line, Groves quit her job. A deeply religious woman, she also lost her church, as she found herself unable to worship alongside managers and scabs.

The tensions reached down to the children as well. Hundreds of young replacement workers moved their families to town and enrolled their children in the schools. Although school administrators told teachers not to take sides in the lockout, some were married to RAC managers and salaried workers and made their company sympathies clear. Fights broke out in schoolyards between children of Local 5668 members and children of replacement workers as they reflected the anger and bitterness they heard at home.

During that first winter and the long wait for unemployment checks, it was particularly difficult for the children of the locked-out workers to listen to the taunts: "I have new Nike shoes. You don't because your daddy isn't working and my daddy is. Your daddy's lazy. He doesn't want his job. My daddy works."

If all the scabs had been strangers-outsiders shipped in by RAC from faraway cities and towns to take their jobs-the situation might have been easier for the locked-out workers. The first busloads of scabs had been brought in from Cleveland, and others came from Florida, New York, Alabama, and Nevada.

But not long after the lockout began, the company began to actively recruit replacement workers from the same communities where the union members lived, shopped, and worshipped. In many cases they were neighbors, in some cases they were relatives. Mostly they were young.

Trapped in low-paying service-sector jobs, often struggling to support their families, they had been denied the American dream that their elders had found in the large aluminum, steel, and chemical plants that dotted the Ohio Valley.

The jobs now available at Ravenswood were good jobs with good wages. They represented for many of these young men and women perhaps their first and only chance for economic security in an area where unemployment rates were twice the national average. 
Most knew that crossing picket lines was wrong. One couldn't grow up so close to the coalfields and not know that. But somehow it was not wrong enough to stop them from crossing the line at Ravenswood Aluminum.

Terry Ashworth became a scab early on in the lockout even though his father was out on the picket line. He told ABC News Nightline, "I lived around here all my life. It's just a decision I made to go in. You work for nothing all your life, you get tired of it. No insurance, no good checks, no overtime."

Two months into the lockout, all but thirteen of the seventeen hundred workers stood firm with the union. Yet, as Dan Stidham and the other local leaders knew, the local was going to have to do something more if it expected people to stay out, especially once their bills started piling up. To win, Joe Chapman told them, "We've got to keep food in their belly. We've got to keep a roof over their heads. We've got to keep the house warm."

The local leaders had planned on unemployment benefits to take care of basic needs. But in the dark days of early December 1990, they recognized that months might pass before unemployment checks would come. Pressure had been building for the union to do something more.

With this in mind, Dan Stidham appointed financial secretary Bud Rose to coordinate the establishment of an "Assistance Center." Rather than use the international strike fund to send individual checks to each worker, as unions typically do during strikes and lockouts, the local leadership decided to pool their resources and base decisions on need.

Stidham described it this way: The International Strike Defense Fund money came in and off the top we went out and bought food. And then we bought insurance for everybody, a basic minimum policy. Each member was getting one hundred dollars [a week from the International]. After you took off the food and insurance, it was something like $\$ 76, \$ 77$ left, which all went in a pool. Each member didn't get the allotted amount-it was based on need. Some members' needs were greater than others'.

There were probably members that never took a dime from up there. Some got everything they could get. Some maybe lived better than they did when they was working, or as good.... So it let that pool build and we were able to help some that were in more dire straits than others.

The center had started rather modestly, assisting with house, car, and utility payments, and providing a small food certificate. But even these decisions were hard.

As Glen Varney, the local treasurer, described the dilemma, "You have to say, 'Did I do right here? Or should I do that? Did I make a car payment last month? Should I make this over here?' So all these things go through your mind, and people don't realize it."

Rose explained, "It's really heartbreaking. This one particular day I remember real clear. Periece Morgan come in and he sit down. He said, 'I just about lost it out there. ... This guy come in and had this stuff, and I told him we'd help him take care of it. He sat there and started crying. I had to leave, I couldn't take it."'

Even with the assistance center, that first winter was a difficult time for the locked-out workers and their families. As Marge Flanigan, the wife of a locked-out worker, remembered, the workers' wives were no less confused and troubled by the lockout than their husbands:

Well, l'll tell you, in December we had one gal that was ready to go over the edge. And she came into the union hall and she begged for us to do something. And what she wanted to do was to go to the plant and have a prayer vigil. ... We parked our cars at the airport.... We had candles and video cameras and we had a prayer vigil and we sang some songs, being filmed by the guards. 
And when we left we were right across from the plant ... and they had left the plant gates open. And we walked ... towards the plant ... to make an impression that we just weren't afraid of them. So we walked across the road. They slammed the gates shut and within three minutes we had state police on us. They said that we had stormed the plant, our candles turned into dynamite, and that we were going to take over the plant. There was like twenty-five, thirty women.

And with this spontaneous action, the wives of the locked-out workers became involved. Realizing that the holiday was going to be difficult for everyone, several women members, together with some of the wives, organized a Christmas party with toys for the 740 children of the locked-out workers.

Buoyed by the success of the Christmas party, the workers' wives decided to organize more formally into the "Women's Support Group." Marge Flanigan and Phyllis Fizer, wife of locked-out worker Joe Fizer, began calling wives, urging them to come to a meeting.

"We met the first time, officially, probably in December of 1990 at the union hall," explained Flanigan. "And it's just a group of women that got together and realized that families are falling apart. They're not going to understand labor disputes, we have lost friends, the families were pitted, our neighbors, the total devastation, the same thing as ... if a tornado destroyed this community. We could rebuild it together."

The hall was packed that night with more than three hundred women. Clearly Marge was not the only spouse who felt total devastation. Many women felt isolated and uninformed, most knowing very little about the lockout or unions.

The Women's Support Group helped to fill that void and gave the women a space to share their ideas, their problems, and their fears. The group also helped bolster the husbands, as they too were learning about solidarity.

Support group member Sue Groves suggested, "[It] ... gave us something to grab hold of. At times we felt that, you know, what can we do? We were beginning to realize that this was going to be a long thing, and that some husbands don't talk to their wives, they don't share things. When this started, it was a source of information, a source of comfort. We shared and cried together, and we relaxed together, and it gave us something to work for."

But, as in the Flint, Michigan, sitdown strikes in 1937, and in the more recent strike by miners against the Pittston Coal Group, the women were much more than a support group. From the first weeks of the lockout, injunctions limited the union to six pickets at each of the picket stations and, with the continued presence of the goon guards and an increasing number of scabs, a feeling of impotence was growing.

Given the stakes, the situation was ripe for violence to erupt. But the local took an entirely different direction with an action organized by the Women's Support Group.

"On January 28 we wanted to do something to let the company know that we were not going to stand by and watch it happen," recalled Marge Flanigan. Shortly after 5 a.m., the women assembled and spent the entire day driving slowly in front of the plant, completely snarling traffic in and out. They repeated it the next day.

"And then, on the second or third day, we got 265 tickets," support group member Linda McCoy reported. "The third day the same amount of tickets, and then the fourth day we'd just take a ticket at random. We told them we already had a ticket. We didn't care if they ticketed us to death, we were not stopping." 
Jim Bowen, the district director of the United Steelworkers, told the women, "Don't pay them. And you go over to that damn magistrate's and you tell them you want a jury hearing, every damn one of you. Pretty soon the state police will say, 'Jesus Christ, we'll be over there all day long."'

The actions came to be known as "drivebys." The police responded by pulling out individual cars and putting them in a "penalty box," as if they were playing a hockey game.

Jim Bowen recalled, "They finally decided we weren't going to pay [the tickets] and they put the penalty box in. I thought it was hilarious. 'You're penalized for one lap!'"

This only made the drive-bys more fun. Some of the men were jealous, because injunctions prohibited them from participating in the drive-bys, so some women put wigs on their husbands and took them along for the ride.

According to the salaried employees, the drive-bys had a tremendous impact inside the plant. "The idea of having to confront the wives of the locked-out workers and the traffic was daunting. Management responded, 'Oh, my God, they're back, they're back,' and everybody wanted to go home," reported a worker who was inside at the time.

Throughout February and early March, the drive-bys continued and were an important focus of the local's activity. On March 23, a judge issued a restraining order prohibiting any further drive-bys. The injunction might have come just in time, before the drive-bys escalated into something beyond the local's control.

As a key local union leader described it, by the end of March the drive-bys had gained a momentum of their own:

The drive-bys were getting bigger.... People were looking forward to it more and more every day. We were getting outsiders coming in and participating. Things were getting out of control. I know that there were federal marshals in those drivethroughs, mixing in with our people and the scabs, and you didn't know who was who. And there were some people that were just out there for whatever, they were having a good time. It was something to do. It took their minds off their real problems. But it could have created some real problems.

You know, someone from outside coming and taking over, guns drawn, maybe shots fired, some beatings, people dragged out of their cars, busted windshields. All that kind of stuff, and it would just get worse and worse. Judge Haden finally put an injunction against us on that, and it probably was for the best.

The drive-bys were important to the union. They solidified the Women's Support Group and silenced any doubters about the women's place in the struggle. And in that first gray winter, the drivebys offered the locked-out workers a way to laugh in the face of management's arrogance.

But the drive-bys, as well as much of the local anti-scab activity, had great limitations as strategy. Beyond letting off steam, they did nothing to leverage management back to the bargaining table or bring the workers back into the plant.

The union campaign was jump-started in the early spring of 1991 with the direct involvement of George Becker, international vice-president of the USWA. Becker assembled a strategy team to conduct a multifaceted campaign in the local and around the world.

This fight had become a personal one for him, and Becker dug in his heels. When faced with criticism or doubt, Becker explained, 
My response to this has always been ... to escalate our activities... I used to call them escalation meetings. The last thing that I wanted that company, Emmett Boyle, to think of before he went to bed at night, Monday, Tuesday, Wednesday, Thursday, Friday, Saturday, and Sunday, is all the problems and difficulties we caused them that day. And the first thing I wanted them to think of when they woke up is, oh, Christ, I've got to go out and face them sons of bitches again.... We had to get them thinking about the Steelworkers continually, every day ... if we let an hour go by that our name didn't cross their minds for some reason or another, then we were failing.

The union launched a massive research effort to learn everything it could about company ownership, assets, investors, customers and vulnerabilities. Union member followed trucks to identify an pressure end-users of RAC aluminum, OSHA and NLRB charges were filed and local union workers traveled across the country to tell their stories. Yet by the summer of 1992, it was clear that to win the workers would need to take the fight to Zug, Switzerland, the hideout of RAC's primary investor, Marc Rich. 